\title{
Scintigraphic Methods to Evaluate Alterations of Gastric and Esophageal Functions in Female Obesity
}

\author{
Kadın Obesitesinde Mide ve Özefagus Fonksiyonlarını Değerlendirmede \\ Sintigrafik Yöntemler
}

\author{
Özgür Ömür1, Mehmet Erdoğan², Hayal Özkılıç1, Candeğer Yılmaz² \\ IEge University Faculty of Medicine, Department of Nuclear Medicine, Izmir, Turkey \\ 2Ege University Faculty of Medicine, Department of Endocrinology and Metabolism, Izmir, Turkey
}

\begin{abstract}
Objective: Altered gastrointestinal function has frequently been observed in obese patients. The aim of this study was to investigate the frequency of gastro-esophageal reflux (GER) and to determine the alterations of gastric emptying and esophageal transit by scintigraphic methods in obese patients.

Methods: Scintigraphic studies of 50 obese female non-diabetic patients who had not received any treatment for weight control were retrospectively reviewed. Mean Body Mass Index (BMI) was $34.96 \pm 3.04 \mathrm{~kg} / \mathrm{m}^{2}$ (range: $32-39 \mathrm{~kg} / \mathrm{m}^{2}$ ). All subjects were submitted to scintigraphic evaluation of esophageal transit, gastro-esophageal reflux, gastric emptying and presence of Helicobacter pylori infection. The data of obese patients were compared with those of sex-age matched 30 non-obese cases who were selected from our clinical archive.

Results: In obese group, seventeen (34\%) patients were found to be GER positive scintigraphically; mean gastric emptying time ( $t 12$ ) was $59.18 \pm 30.8 \mathrm{~min}$ and the mean esophageal transit time was $8.9 \pm 7.2 \mathrm{~s}$. Frequency of positive GER scintigraphy and the mean value of esophageal transit time were significantly higher in obese patients than non-obese control subjects. Gastric emptying time and esophageal transit time values were significantly longer in GER positive obese patients than GER negative ones. There was no statistically significant difference in the frequency of positive C14 urea breath test between obese and non-obese subjects and there were also no statistically significant correlations between BMI, GER, esophageal transit time and gastric emptying time.

Conclusion: In our study, 42 of the 50 obese patients had esophago-gastric motility alterations. The significance of these alterations in obesity is not fully understood, but it is believed that these changes could be because of potential contributing factors in the development or maintenance of obesity or changes in eating habits.
\end{abstract}

Key words: Obesity, esophageal motility disorders, gastroesophageal reflux

\begin{abstract}
Özet
Amaç: Obezitede gastrointestinal fonksiyon değişiklikleri sıklıkla meydana gelmektedir. Bu çalışmada obez olgularda gastroözefageal reflü (GÖR) sıklığını araştırmak, mide boşalım ve özefagus transit zamanlarındaki değişiklikleri sintigrafik yöntemlerle değerlendirmek amaçlandı.

Yöntem: Kilo kontrolüne yönelik tedavi almayan, diyabetik olmayan 50 kadın obez olguya ait veriler retrospektif olarak incelendi. Ortalama Vücut Kitle İndeksi (BMI) $34.96 \pm 3.04 \mathrm{~kg} / \mathrm{m}^{2}$ idi (değer aralığı: $32-39 \mathrm{~kg} / \mathrm{m}^{2}$ ). Tüm olgularda özefagus transit ve mide boşalım zamanları, gastroözefageal reflü varlığı sintigrafik yöntemlerle değerlendirildi. Elde edilen veriler klinik arşivimizde bulunan yaşları uyumlu obez olmayan 30 kadın olguya ait sonuçlar ile karşılaştırıldı.

Bulgular: Obez grupta 17 olguda (34\%) sintigrafik olarak gastroözefageal reflü saptandı. Ortalama mide boşalım yarı zamanı ( $\mathrm{t} 12$ ) $59,18 \pm 30,8 \mathrm{dk}$, ortalama özefagus transit zamanı ise $8,9 \pm 7,2$ saniye idi. GÖR sıklığı ve ortalama özefagus transit zamanı obez grupta kontrol grubuna gore anlamlı yüksek bulundu. Mide boşalım ve özefagus transit zamanları GÖR saptanan obez olgularda, GÖR saptanmayanlardan anlamlı yüksekti. Obez ve obez olmayan olgular arasında C14 üre nefes testi pozitifliği açısından anlamlı fark bulunmadı. Vücut kitle indeksi ile GÖR, özefagus transit ve mide boşalım zamanları arasında anlamlı korelasyon saptanmadı.
\end{abstract}

Address for Correspondence: Özgür Ömür MD, Ege University Faculty of Medicine, Department of Nuclear Medicine, İzmir, Turkey Phone: +90 2323904780 E-mail: ozomur@yahoo.com Received: 31.05.2013 Accepted: 04.10.2013 
Sonuç: Bu çalışmaya dahil edilen 50 obez olgunun 42'sinde mide-özefagus motilite değişiklikleri mevcuttu. Obezitede bu değişikliklerin neden-sonuç ilişkisi henüz tam anlaşılamamakla birlikte obezitenin oluşumu, korunması ya da beslenme alışkanlıklarında potansiyel etkileri olabileceği düşünülmüştür.

Anahtar kelimeler: Obezite, özefagus hareket bozuklukları, gastroözefageal reflü

\section{Introduction}

Obesity is a medical condition in which the body mass index (BMI) of a person exceeds $30 \mathrm{~kg} / \mathrm{m}^{2}$. It has become the most common chronic health problem in many countries. In the United States alone, obesity is currently the second leading cause of preventable death, with more than $50 \%$ of adults estimated as being overweight or obese and $5 \%$ as being morbidly obese $(1,2,3)$. Obese individuals have increased incidence of medical problems including coronary artery disease, hypertension, peripheral vascular disease, pulmonary insufficiency, sleep apnea, diabetes, osteoarthritis, and gastro-esophageal reflux disease (GERD), together with psychosocial disabilities.

GERD is the most common pathologic condition of the foregut in the Western World and accounts for about $75 \%$ of all esophageal diseases $(4,5)$. Obesity and GERD show a prevalence of $30 \%$ and $15-20 \%$, respectively, in adults in Western countries $(6,7)$. Obesity is a predisposing factor to GERD, but in obese patients, esophageal function still remains poorly studied (8). The evaluation of esophageal physiology in laboratory has been increasingly used to understand and manage symptoms such as heartburn, regurgitation, atypical reflux symptoms, chest pain, and dysphagia. Among several diagnostic techniques, esophageal manometry and 24-h pH monitoring are still employed in the clinical practice $(9,10,11)$. Altered gastrointestinal functions, esophageal motility disorders and a higher incidence in the Helicobacter pylori infection have been also reported in obese subjects $(12,13,14,15,16,17,18,19)$. In this study, we aimed to evaluate the presence of GERD, Helicobacter pylori infection and gastric-esophageal motility alterations in obese patients by nuclear medicine methods.

\section{Materials and Methods}

\section{Patients}

Scintigraphic studies of 50 non-diabetic obese (BMI $\geq 30$ ) female patients who had not received any treatment for weight control or gastro-esophageal symptoms were retrospectively reviewed. The mean age was $49.6 \pm 8.1$ years and the mean BMl was found as $34.96 \pm 3.04 \mathrm{~kg} /$ $\mathrm{m}^{2}$ (range: $32-39 \mathrm{~kg} / \mathrm{m}^{2}$ ). Patients neither have any other systemic disease nor have any medications that may affect gastro-esophageal functions. All subjects were submitted to scintigraphic evaluation of esophageal transit, gastro- esophageal reflux and gastric emptying. C-14 urea breath test was also performed to all of the patients to assess the presence of helicobacter pylori infection. Informed consents were obtained from all patients. The data of obese patients were compared with those of sex-age matched 30 non-obese cases who were selected from our clinical archive.

\section{Scintigraphic Studies}

\section{Scintigraphic Evaluation of Esophageal Transit}

The subjects were studied while sitting in front of the collimator of the gamma camera, facing forward, and head at midline during the scintigraphic examination. All patients were given $15 \mathrm{ml}$ water containing $0.5 \mathrm{mCi}(18.5$ $\mathrm{MBq}$ ) Tc-99m labeled diethylene triamine pentaacetate (DTPA). The patients were instructed to hold the mouthful of the prepared water in their mouth for a few seconds and then swallow it when the examiner gave a sign. Dynamic acquisitions in a 64x64 matrix were performed with large-field-of-view gamma camera (Toshiba GCA602A) equipped with low energy all-purpose parallel hole collimator (LEAP). During the study, 20 transit images were recorded at $0.5 \mathrm{~s}$ intervals. Regions of interests (ROIs) were outlined on the esophagus and then the time-activity curves (TAC) were created. From this TAC, esophageal transit time was calculated using a software programme. The observation of the peak activity on the TAC within $10 \mathrm{~s}$ was accepted as normal esophageal clearance.

\section{Scintigraphic Evaluation of Gastro-esophageal Reflux}

Gastro-esophageal reflux scintigraphy was performed after esophageal transit study without giving the patient any other radioactivity. Following the esophageal transit study, the patients were given additional water to washout oropharyngeal and esophageal residual activity. After this procedure, patients were re-positioned supine under the gamma camera (Toshiba GCA-602A) equipped with a LEAP collimator. Dynamic imaging was performed in 64x64 matrix with 60-s frames for 30 min. TACs were derived from ROls drawn over the esophagus and stomach. TACs were analyzed and additionally all images were visually evaluated. Detection of the activity in the esophagus on the images visually or detection of one or more peaks on TACs at any time during the scintigraphic 
evaluation was considered as gastro-esophageal reflux. Peaks which displayed a two-fold or more increment in the esophageal counts over the baseline were accepted as reflux episode.

\section{Scintigraphic Evaluation of Gastric Emptying}

Scintigraphic assessment of solid phase gastric emptying was performed in fasting state for at least 4 h. The test meal composed of an egg sandwich (bread approximately $200 \mathrm{~g}$ ) labeled with $0.5 \mathrm{mCi}(18.5 \mathrm{MBq}) \mathrm{Tc}-$ $99 \mathrm{~m}$ DTPA. The patients were asked to eat the sandwich within $5 \mathrm{~min}$. Immediately after ingestion of the meal, patients were positioned supine under a large field-ofview dual headed gamma camera (Sophy DST) equipped with LEAP collimator. Attenuation and decay corrections were made by software program. Images were recorded in a $64 \times 64$ matrix in 30-s frames for $60 \mathrm{~min}$. After $60^{\text {th }}$ min, planar images were obtained with an interval of 15 min until $2^{\text {th }}$, consecutively. TACs were created from an irregular ROI drawn over the stomach and geometric mean of the anterior and posterior gastric counts was used. Gastric emptying was expressed as the half time of emptying ( $\left.t^{1} / 2\right)$ and determined as the time it takes to reach half of the peak counts calculated from TAC.

\section{C14 Urea Breath Test}

Medications such as antibiotics and bismuth compounds were withdrawn 30 days before the test while withdrawal period for sucralfate and proton pump inhibitors were two weeks. C14 urea in a capsule form containing $1 \mathrm{mg}$ urea labeled with $37 \mathrm{kBq}(1 \mu \mathrm{Ci}) \mathrm{C} 14$ was used for the test after at least $6 \mathrm{~h}$ starvation. Patients swallowed this capsule with $20 \mathrm{ml}$ of water. At $10 \mathrm{~min}$ post-dose, patients were asked to take a deep breath, hold it for approximately 5-10 s and then exhale through a straw into a Mylar balloon. Balloons with breath samples were calculated in the scintillation counter. Reference values are as follows: $<50 \mathrm{dpm}$ : Negative, 50-199 dpm: Indeterminate and $\geq 200 \mathrm{dpm}$ : Positive for $\mathrm{H}$. pylori. If a value of $50-200 \mathrm{dpm}$ was obtained, the samples were recounted in $1-2 \mathrm{~h}$ or the next day.

\section{Statistical Analysis}

The mean values and standard error of the means of all measured quantities were calculated. Clinical and scintigraphic parameters of subgroups of the patients such as gastric emptying and esophageal transit half times, BMI and age were compared using 2-tailed Student $t$ test for unpaired samples. Correlation between GER and C14 urea breath test positivity, gastric emptying-esophageal transit half time or BMI was done with Spearman's correlation test. Differences between some numerical parameters of the obese and non-obese control subjects were evaluated using Fischer's exact test. $\mathrm{P}<0.05$ is considered as statistically significant.

\section{Results}

In 50 obese cases, 42 patients had one or more positive scintigraphic findings associated with gastrointestinal system. Seventeen of 50 obese patients were found to be GER positive scintigraphically and 29 patients had positive C14 urea breath test. In non-obese control group, 4 cases were positive for GER and 14 cases were positive for $\mathrm{C} 14$ urea breath test. The mean gastric emptying time $\left(\mathrm{t}^{1} / 2\right)$ and the mean esophageal transit time was $59.18 \pm 30.8$ min and $8.9 \pm 7.2 \mathrm{~s}$ in obese subjects, respectively, while they were $50.3 \pm 29.2 \mathrm{~min}$ and $6.9 \pm 3.4 \mathrm{~s}$ for non-obese case group, respectively. Frequency of GER positivity and the mean esophageal transit time were significantly higher in obese patients than non-obese cases $(p=0.02$ and 0.04 respectively). The summary of the clinical and scintigraphic parameters of the obese patients and non-obese subjects are presented in Table 1.

According to the comparison made between GER positive and GER negative patients (Table 2), the mean gastric emptying time was found as $64.9 \pm 29.2$ and $53.3 \pm 30.2 \mathrm{~min}$, respectively.

The comparison of gastric emptying time between GER positive and negative patients was statistically significant $(p=0.03)$. The mean esophageal transit time was also significantly longer in GER positive patients (11.2 $\pm 7.3 \mathrm{~s})$

Table 1. Scintigraphic and clinical parameters of the whole study group

\begin{tabular}{lccc}
\hline PARAMETERS & Obese subjects & Non-obese control subjects & p \\
\hline Number of patients & 50 & 40 & 0.9 \\
Mean age (years) & $49.6 \pm 8.1$ & $22.8 \pm 1.4$ & $0.001^{*}$ \\
Mean BMI (kg/m²) & $34.96 \pm 3.04$ & $4 / 30(13 \%)$ & $0.02^{*}$ \\
GER positive patients & $17 / 50(34 \%)$ & $14 / 30(46.6 \%)$ & 0.1 \\
C14 urea breath test positive patients & $29 / 50(52 \%)$ & $50.3 \pm 29.2$ & 0.09 \\
Mean gastric emptying time (t $1 / 2)(\min )$ & $59.18 \pm 30.8$ & $6.9 \pm 3.4$ & $0.04^{*}$ \\
Mean esophageal clearance time $(\mathrm{t} 1 / 2)(\mathrm{sec})$ & $8.9 \pm 7.2$ & &
\end{tabular}


Table 2. A comparison of scintigraphic and clinical parameters of GER positive and GER negative obese patients

\begin{tabular}{|c|c|c|c|}
\hline Parameters & GER - Positive & GER - Negative & p \\
\hline Number of patients & 17 & 33 & \\
\hline Mean age (years) & $49.58 \pm 8.31$ & $49.64 \pm 8.17$ & 0.92 \\
\hline Mean BMI $\left(\mathrm{kg} / \mathrm{m}^{2}\right)$ & $34.83 \pm 3.04$ & $34.96 \pm 3.04$ & 0.94 \\
\hline Mean gastric emptying time $\left(t^{1} 1 / 2\right)(\min )$ & $64.9 \pm 29.2$ & $53.3 \pm 30.2$ & $0.03^{*}$ \\
\hline Number of patients with Gastric emptying time $\left(t^{1} 1 / 2\right)>90$ min & $3 / 17(17 \%)$ & $2 / 33$ pts (6\%) & $0.009 *$ \\
\hline Mean esophageal clearance time $\left(t^{1} / 2\right)(\mathrm{sec})$ & $11.2 \pm 7.3$ & $8.2 \pm 7.2$ & $0.039 *$ \\
\hline Number of patients with Esophageal clearance time $(t 1 / 2)>10 \mathrm{sec}$ & $7 / 17(47 \%)$ & $6 / 33(18 \%)$ & $0.008^{*}$ \\
\hline Number of patients with positive C14 urea breath & $10 / 17(58 \%)$ & $19 / 33(57 \%)$ & 0.89 \\
\hline
\end{tabular}

Table 3. Characteristics of patient groups with gastric emptying time shorter and longer than normal reference values (45-90 $\mathrm{min})$

\begin{tabular}{|c|c|c|c|}
\hline Gastric emptying time & $\geq 90 \mathrm{~min}$ & $45-90 \mathrm{~min}$ & $<45 \min$ \\
\hline Number of patients & 5 & 26 & 19 \\
\hline Mean age (years) & $52.2 \pm 7.8$ & $49.54 \pm 8.3$ & $49.64 \pm 8.2$ \\
\hline Mean BMI (kg/m²) & $34.3 \pm 2.8$ & $34.8 \pm 3.04$ & $34.9 \pm 3.04$ \\
\hline Mean esophageal clearance time $\left(\mathrm{t}^{1} / 2\right)(\mathrm{sec})$ & $9.31 \pm 9.4$ & $8.3 \pm 7.2$ & $7.89 \pm 7.13$ \\
\hline Number of patients with Esophageal clearance time $\left(t^{1} / 2\right)>10 \mathrm{sec}$ & $2 / 5(40 \%)$ & $8 / 26(30 \%)$ & $3 / 19(15 \%)$ \\
\hline Number of patients with positive GER & $3 / 5(40 \%)$ & $11 / 26(42 \%)$ & $3 / 19(15 \%)$ \\
\hline Number of patients with positive C14 urea breath test & $2 / 5(40 \%)$ & $15 / 26(57 \%)$ & $12 / 19(63 \%)$ \\
\hline
\end{tabular}

Table 4. Characteristics of patient groups with esophageal clearance time longer than normal reference value ( $>10$ sec)

\begin{tabular}{|c|c|c|c|}
\hline Esophageal clearance time & $>10 \mathrm{sec}$ & $\leq 10 \mathrm{sec}$ & $\mathbf{p}$ \\
\hline Number of patients & 13 & 37 & \\
\hline Mean age (years) & $49.6 \pm 8.2$ & $49.6 \pm 8.3$ & 0.93 \\
\hline Mean BMI (kg/m²) & $34.7 \pm 2.9$ & $34.9 \pm 3.04$ & 0.94 \\
\hline Mean gastric emptying time $(\mathrm{t} 1 / 2)(\mathrm{min})$ & $58.9 \pm 30.8$ & $57.6 \pm 30.8$ & 0.82 \\
\hline Patients with gastric emptying time $\left(t \frac{1}{2}\right)>90 \mathrm{~min}$ & $2 / 13(15 \%)$ & $3 / 37(8 \%)$ & $0.03^{*}$ \\
\hline GER positive patients & $7 / 13(53 \%)$ & $10 / 37(27 \%)$ & $0.03^{*}$ \\
\hline C14 urea breath test positive patients & $8 / 13(61 \%)$ & $21 / 37(56 \%)$ & 0.71 \\
\hline
\end{tabular}

than GER negative patients (8.2 $27.2 \mathrm{~s})$ ( $p=0.039)$. Positive correlations were determined between GER positivity and $t 1 / 2$ values of gastric emptying and esophageal transit, which were significantly longer in GER positive obese patients $(p=0.036)$.

In 19 of the 50 obese patients, gastric emptying time

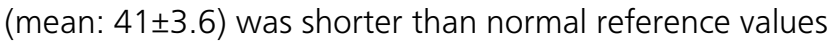
(<45 min). In these patients the mean esophageal transit time was $7.89 \pm 7.13 \mathrm{~s}$ and the rate of GER positivity (\%15) was lower than those with a normal reference values and prolonged gastric emptying time. The frequency of positive C14 urea breath test was significantly higher in these patients than that of the prolonged gastric emptying $(p=0.02)$ (Table 3). Gastric emptying time was longer than normal reference values in 5 obese patients. In these cases, mean esophageal transit time and frequency of GER positivity were significantly higher; while C14 urea breath test positivity was lower than the other groups (Table 3).

In 13 of 50 obese patients, esophageal transit time was longer than $10 \mathrm{~s}$ and 7 of these patients were found to be GER positive. There was no statistically significant 
difference between gastric emptying time and C14 urea breath test positivity in patients with normal and prolonged esophageal transit time (Table 4).

No statistically significant correlation was found considering the relationship between BMI and other variables such as GER positivity, esophageal transit time, and gastric emptying time.

\section{Discussion}

Gastrointestinal (GI) system motility plays a critical role in consumption of foods, digestion and absorption of nutrients. Gl motility not only regulates the absorption of nutrients, but also participates in the control of appetite (12). While the significance of altered Gl functions in obesity is not fully understood, altered Gl motility has been frequently observed in obese patients and suggested to be important in the development of obesity and eating attitude (12). Among several co-morbidities associated with obesity and GERD has been reported to be prevalent also $(13,14,15,16)$. Esophageal motility disorders and altered gastric functions may be accompanied by GERD in obese patients $(16,17,18,19)$. Nearly all epidemiologic studies have found an association between increasing BMI and symptoms of GERD. Changes in gastro esophageal anatomy and physiology caused by obesity may explain the association $(13,14,15,16,17,18,19)$. These include an increased prevalence of esophageal motor disorders, diminished lower esophageal sphincter (LES) pressure, the development of a hiatal hernia and increased intragastric pressure (20). Additionally, metabolic, hormonal or behavioral factors may be involved in the etiology of obesity.

Gender differences in obesity and its effect on GI functions were also evaluated in the literature. Delayed gastric emptying which was assessed using non-invasive 13C-octanoic acid breath test (21), slower gastric emptying in patients taking oral sex hormone replacement (22), higher incidence of GERD (23) and increased risk of esophageal disorders such as adenocarcinoma, Barrett esophagus and GERD predominantly abdominal or intraabdominal adiposity (24) have been reported in female obesity.

Although there were several studies about GERD, esophageal dysmotility and gastric functions in obese patients, to the best of our knowledge there was no study evaluating combined gastric-esophageal functions and GERD by scintigraphic methods in obese individuals. In this study, the presence of GERD, alterations of esophageal and gastric functions were investigated and the interrelationship between all of these parameters with obesity was examined.

Our results revealed that the presence of GER in obese patient group (34\%) was significantly higher than that of non-obese cases (13\%). The mean gastric emptying time was as expected in significantly higher but normal reference ranges in GER positive obese patients when compared to GER negative obese patients (64.9 $\pm 29.2 \mathrm{~min}$ vs. $53.3 \pm 30.2 \mathrm{~min}$, respectively). The mean esophageal transit time was also significantly longer in GER positive obese patients $(11.2 \pm 7.3 \mathrm{~s})$ than GER negative obese patients $(8.2 \pm 7.2 \mathrm{~s})$ and non-obese cases $(6.9 \pm 3.4 \mathrm{~s})$. It was shown by different studies that gastric emptying and esophageal transit were significantly delayed in patients with GERD $(25,26)$. In this study, the mean gastric emptying time was not prolonged in whole study group and in the subgroup of GER positive patients. However, number of patients with delayed gastric emptying and the mean gastric emptying time were significantly higher in GER positive patients (Table 2). It may be speculated that the motility abnormalities that cause GERD can also cause delayed gastric emptying by the similar mechanism or contrarily delayed gastric emptying may contribute to the development of GERD. Although there were various studies about esophageal motility abnormalities after gastric banding surgery in obese patients, the evaluation of esophageal functions in non-operated obese cases especially using radionuclide methodologies still remains insufficient $(6,8)$.

In agreement with our results, Mercer CD et al. have reported that the esophageal transit time as measured by radionuclide methods was significantly prolonged in obese group as compared with normal population (27). But a factor that may affect esophageal transit, GER, has not been evaluated in this study. Additionally, increased transient lower esophageal sphincter (LES) relaxation, stronger peristalsis, increased acid exposure regardless of presence of GERD have been reported in obese cases $(11,28)$. In obese patient group of our study, the mean esophageal transit time $(8.9 \pm 7.2 \mathrm{~s})$ was not longer than the normal reference (<10 s), but significantly longer than that of non-obese subjects. Thirteen of 50 obese patients had delayed esophageal transit time. Nearly half of these patients had GER and it's remarkable that the mean esophageal transit time in obese patients with GER was found significantly longer than GER negative cases (Tables 3 and 4). Gastric emptying time was also significantly longer in patients with delayed esophageal transit than the others. For this reason, contribution of GER on esophageal transit and gastric functions was considered in obese patients. Several studies proved that the development of GERD was usually associated with a decreased LES pressure, increased transient LES relaxations and decreased esophageal clearance capacity $(8,11,12)$.

Accelerated gastric emptying was found in 19 of 50 obese cases (38\%). Most of the studies that investigate gastric motility in obese patients have also reported 
accelerated gastric emptying of solids $(12,19,29,30)$. In the current study, there was no significant difference in mean gastric emptying time in obese and non-obese subjects. Similarly, no significant association was determined between esophago-gastric parameters or presence of GER and BMI. Our patient group to be uniform in terms of age and BMI may lead to this situation.

In this study group, 29 of the 50 obese patients had positive C14 urea breath test as the indicator of Helicobacter pylori infection. There was no significant association between C14 urea breath test positivity and esophageal transit or presence of GER. However, the number of patients with positive C14 urea breath test was significantly higher in subgroup of patients with shorter gastric emptying half time than longer ones. Epidemiological studies suggested that the frequency of helicobacter pylori infection in asymptomatic population ranged from 10\% to $60 \%$ (31). Metabolic and endocrinological syndromes or obesity that might be accompanied with Helicobacter pylori infection have also been reported $(15,32,33)$. AlAkawaa AM noted that prevalence of Helicobacter pylori infection in morbidly obese Saudi patients was about $85 \%$ (34). Although, C14 urea breathe test is the screening test for evaluating Helicobacter pylori infection, frequency of this infection (58\%) was not so different in our obese cases than reported in normal population range (10-60\%) and our non-obese control subjects (46\%). These results may suggest that the lack of morbidly obese patients (BMl>40 $\mathrm{kg} / \mathrm{m}^{2}$ ) in our study group could be responsible for this condition.

The major limitation of the study was gastric emptying time evaluations were based on the calculation of department normals. The lack of standardization of the method of analysis may cause some problems in interpreting results. Reported values of gastric emptying are influenced by the duration of testing and the method of analysis (35).

Taken together all these results suggest that esophageal and gastric motility alterations play an important role on pathophysiology of obesity. However, each patient may have different motility alterations and, therefore case based analysis is necessary for modification of the treatment strategy. As a conclusion, scintigraphic studies can be used for the evaluation of GI motility alterations in obese subjects as they are non-invasive, easily applicable methods with a very low radiation exposure.

\section{References}

1. Monkhouse SJ, Morgan JD, Bates SE, Norton SA. An Overview of the Management of Morbid Obesity. Postgrad Med J 2009;85:678681.

2. Flegal $\mathrm{KM}$, Carroll $\mathrm{MD}$, Ogden $\mathrm{CL}$, Johnson $\mathrm{CL}$. Prevalence and trends in obesity among US adults, 1999-2000. JAMA 2002;288:1723-1727
3. Freedman DS, Khan LK, Serdula MK, Galuska DA, Dietz WH. Trends and correlates of class 3 obesity in United States from 1990 through 2000. JAMA 2002;288:1758-1761

4. Trus TL, Hunter JG. Minimally invasive surgery of the esophagus and stomach. Am J Surg 1997;173:242-255.

5. Klaus A, Weiss $H$. Is preoperative manometry in restrictive bariatric procedures necessary? Obes Surg 2008;18:1039-1042.

6. Rebecchi F, Rocchietto S, Giaccone C, Talha A, Morino M. Gastroesophageal reflux disease and esophageal motility in morbidly obese patients submitted to laparoscopic adjustable silicone gastric banding or laparoscopic vertical banded gastroplasty. Surg Endosc 2011;25:795-803.

7. De Marco S, Passaglia C. Obesity and gastroesophageal reflux disease. Recenti Prog Med 2010;10:106-111.

8. Merrouche $M$, Sabaté JM, Jouet $P$, Harnois F, Scaringi $S$, Coffin B, Msika S. Gastro-esophageal reflux and esophageal motility disorders in morbidly obese patients before and after bariatric surgery. Obes Surg 2007;17:894-900.

9. Hirano I, Richter JE. ACG practice guidelines: Esophageal reflux testing. Am J Gastroenterol. 2007;102:668-685.

10. Pandolfino JE, Kahrilas PJ. AGA technical review on the clinical use of esophageal manometry. Gastroenterology 2005;128:209-224.

11. Fornari F, Callegari-Jacques SM, Dantas RO, Scarsi AL, Ruas LO, de Barros SG. Obese patients have stronger peristalsis and increased acid exposure in the esophagus. Dig Dis Sci 2011;56:1420-1426.

12. Xing J, Chen JDZ. Alterations of gastrointestinal motility in obesity. Obes Res 2001;12:1723-1732.

13. El-Serag $\mathrm{H}$. The association between obesity and GERD: A review of the epidemiological evidence. Dig Dis Sci 2008;53:2307-2312.

14. Hampel H, Abraham NS, El-Serag HB. Meta-analysis: Obesity and the risk for gastro esophageal reflux disease and its complications. Ann Intern Med 2005;143:199-211.

15. Roman S, Pandolfino JE. Environmental-Lifestyle related factors. Best Pract Res Clin Gastroenterol 2010;24:847-859.

16. Fornari F, Callegari-Jacques SM, Dantas RO, Scarsi AL, Ruas LO, Silva de Barros SG. Obese patients have stronger peristalsis and increased acid exposure in the esophagus. Dig Dis Sci 2011;56:1420-1426.

17. Lagergren J. Influence of obesity on the risk of esophageal disorders. Nat Rev Gastroenterol Hepatol 2011;8:340-347.

18. Stacher G, Lenglinger J, Eisler M, Hoffmann H, Goll A, Bergmann $H$, Stacher-Janotta G. Esophageal acid exposure in upright and recumbent postures: role of esophageal sphincter, esophageal contractile and transport function, hiatal hernia, age, sex, and body mass. Dig Dis Sci 2006;51:1896-1903.

19. Bertin E, Schneider N, Abdelli N, Wampach H, Cadiot G, Loboguerrero A, Leutenegger M, Liehn JC, Thiefin G. Gastric emptying is accelerated in obese type 2 diabetic patients without autonomic neuropathy. Diabetes Metab (Paris) 2001;27:357-364.

20. Friedenberg FK, Xanthopoulos M, Foster GD, Richter JE. The association between gastroesophageal reflux disease and obesity. Am J Gastroenterol 2008;103:2111-2122.

21. Jackson SJ, Leahy FE, McGowan AA, Bluck LJ, Coward WA, Jebb $\mathrm{SA}$. Delayed gastric emptying in the obese: an assessment using the non-invasive (13) C-octanoic acid breath test. Diabetes Obes Metab 2004;6:264-270.

22. Hutson WR, Roehrkasse RL, Wald A. Influence of gender and menopause on gastric emptying and motility. Gastroenterology 1989;96:11-17.

23. Lee SW, Lien HC, Chang CS, Peng YC, Ko CW, Chou MC. Impact of body mass index and gender on quality of life in patients with gastroesophageal reflux disease. World I Gastroenterol 2012;18:5090-5095.

24. Lagergren J. Influence of obesity on the risk of esophageal disorders. Nat Rev Gastroenterol Hepatol 2011;8:340-347. 
25. Savarino E, Gemignani L, Pohl D, Zentilin P, Dulbecco P, Assandri L, Marabotto E, Bonfanti D, Inferrera S, Fazio V, Malesci A, Tutuian R, Savarino V. Oesophageal motility and bolus transit abnormalities increase in parallel with the severity of gastro-oesophageal reflux disease. Aliment Pharmacol Ther 2011:34:476-486.

26. Caldaro T, Garganese MC, Torroni F, Ciofetta G, De Angelis $P$, di Abriola GF, Foschia F, Rea F, Romeo E, Dall'Oglio L. Delayed gastric emptying and typical scintigraphic gastric curves in children with gastroesophageal reflux disease: could pyloromyotomy improve this condition? J Pediatr Surg 2011;46:863-869.

27. Mercer CD, Rue C, Hanelin L, Hill LD. Effect of obesity on esophageal transit. Am J Surg 1985:149:177-181.

28. Wu JC, Mui LM, Cheung CM, Chan Y, Sung JJ. Obesity is associated with increased transient lower esophageal sphincter relaxation. Gastroenterology 2007;132:883-889.

29. Tosetti C, Corinaldesi R, Stanghellini V, Pasquali R, Corbelli C, Zoccoli G, Di Febo G, Monetti N, Barbara L. Gastric emptying of solids in morbid obesity. Int J Obes Relat Metab Disord 1996;20:200-205.

30. Jones TF, Lin Z, Sarosiek I, Moncure M, McCallum RW. Assessment of gastric emptying and myoelectric activity in the morbidly obese patients. Gastroenterology 2001;120:A1500.
31. Ford AC, Axon AT. Epidemiology of helicobacter pylori infection and public health implications. Helicobacter 2010;15:1-6.

32. Jafery PL, McGuckin MA, Linden SK. Endocrine impact of helicobacter pylori: focus on ghrelin and ghrelin o-acyltransferase. World J Gastroenterol 2011;17:1249-1260.

33. Albaker WI. Helicobacter pylori infection and its relationship to metabolic syndrome: is it myth or fact? Saudi J Gastroenterol 2011;17:165-169

34. Al-Akawaa AM. Prevalence of helicobacter pylori infection in a group of morbidly obese Saudi patients undergoing bariatric surgery. A preliminary report. Saudi J Gastroenterol 2010;16:264267.

35. Abell TL, Camilleri M, Donohoe K, Hasler WL, Lin HC, Maurer AH, McCallum RW, Nowak T, Nusynowitz ML, Parkman HP, Shreve P, Szarka LA, Snape WJ, Ziessman HA. Consensus Recommendations for Gastric Emptying Scintigraphy: A Joint Report of the American Neurogastroenterology and Motility Society and the Society of Nuclear Medicine. Am J Gastroenterol 2008;103:753-763. 